\title{
Perubahan Status Kelembagaan dan Kualitas Pelayanan Pasien Rumah Sakit
}

\section{The Changing of Institutional Status and Quality of Hospital Patient Care in Hospital}

\author{
Dadang Kusnadi
}

Program Studi Ilmu Kesehatan Masyarakat Fakultas Kedokteran Universitas Padjadjaran

\begin{abstract}
Abstrak
Kenyamanan, keamanan, dan kepuasan pelayanan pasien merupakan fenomena pelayanan yang mencerminkan kualitas. Tujuan penelitian ini adalah untuk mengetahui pengaruh implementasi kebijakan perubahan status kelembagaan rumah sakit terhadap kualitas pelayanan pasien. Penelitian ini menggunakan desain kuantitatif dan metode explanatory survey. Metode analisis meliputi regresi linier multipel dengan uji validitas product moment pearson, uji reliabilitas teknik alpha cronbach, uji hipotesis path analysis dan uji statistik (t), serta transformasi data skala likert dengan alat ukur method of succesive interval. Populasi adalah pegawai rumah sakit sebanyak 1.072 orang dan sampel sebanyak 92 orang yang ditentukan dengan teknik stratified random sampling. Data dikumpulkan dengan wawancara terstruktur menggunakan kuesioner dan wawancara pasien sebagai counter informan. Hasil penelitian menunjukkan bahwa implementasi kebijakan perubahan status kelembagaan rumah sakit secara signifikan terbukti berpengaruh terhadap kualitas pelayanan pasien sekitar 66,31\% dan faktor lain berpengaruh sebesar (e) 33,69\%. Berbagai faktor yang berpengaruh positif signifikan terhadap kualitas pelayanan meliputi faktor komunikasi $(0,49 \%)$, sumber daya $(0,25 \%)$, sikap pelaksana $(0,32 \%)$, dan struktur birokrasi $(0,33 \%)$. Faktor lain yang memengaruhi kualitas pelayanan adalah faktor budaya kerja sebagai norma implementasi kebijakan perubahan status kelembagaan rumah sakit.

Kata kunci: Implementasi kebijakan, status kelembagaan rumah sakit, kualitas pelayanan
\end{abstract}

\section{Abstract}

Comfort, safety, and satisfacton of patient care is a phenomenon that represents service quality. This research intends to uncover effects on implementation of the changing of institutional status towards quality of patient care. Ths research used quantitative research design with explanatory survey method. Analysis method including multiple linear regression with pearson product moment test validity, reliability test techniques and test hy- potheses alpha cronbach path analysis, and testing statistic (t), and also data transform likert scale which uses method of successive interval tool. The research population is 1.072 employees and 92 person sample taken by stratified random sampling. Data collected by structured interview using questionnaire and patient interviews as counter informan. Results showed that the implementation of policy change on institutional status of hospital proven the of significant influence on the quality of patient cares at $66,31 \%$ and other factors influenced (e) 33,69\%. Various factors that affect significantly positive on quality service including communication factor $12,49 \%$; resources $0,25 \%$; attitude of the implementers $0,32 \%$; and bureaucratic structure $0,33 \%$. Another concept that influenced of quality care is job behavior factor as implementation of policy change on institutional status of hospital norm.

Key words: Implementation policy, hospital institution status, quality service

\section{Pendahuluan}

Sampai sekarang, kualitas kinerja dan citra rumah sakit yang merupakan pelayanan masyarakat masih tergolong rendah. ${ }^{1}$ Pengelolaan pelayanan rumah sakit pemerintah terkesan belum sesuai dengan harapan dan tuntutan masyarakat. Kenyamanan, keamanan, dan kepuasan pasien yang merupakan indikator kualitas pelayanan rumah sakit pemerintah masih tergolong rendah. Hal tersebut terjadi akibat komunikasi, sumber daya manusia, sikap perilaku, dan struktur birokrasi yang tidak mendukung. ${ }^{2}$ Pemerintah berupaya meningkatkan citra pelayanan rumah sakit dengan mengubah kebijakan peraturan yang mengarah pada good governance dan good

Alamat Korespondensi: Dadang Kusnadi, Program Studi Ilmu Kesehatan Masyarakat FK Universitas Padjadjaran, Jl. Prof. Eyckman No. 38 Bandung 40161, Hp.0818223928, e-mail: dadangkusnadi@ymail.com 
clinical governance. ${ }^{3}$ Otonomi manajemen rumah sakit akan memengaruhi pengambilan keputusan dan status kelembagaan yang merupakan isu penting dalam menjawab tantangan mutu layanan kesehatan masyarakat.,4,5

Perubahan status badan hukum rumah sakit bertujuan untuk meningkatkan kinerja rumah sakit dalam memberikan pelayanan kepada masyarakat. ${ }^{6}$ Hal tersebut diharapkan mampu menciptakan pengelolaan pelayanan prima, kemandirian, efisiensi, fleksibilitas, dan produktivitas. ${ }^{6}$ Administrator rumah sakit berfungsi strategis dalam memudahkan pencapaian kemandirian rumah sakit. ${ }^{7}$ Masalah pelayanan pasien di rumah sakit mengekspresikan kesenjangan antara realita yang nyata dan yang diharapkan pasien. Pada kenyataannya, pelayanan pada pasien belum memenuhi harapan dan tuntutan masyarakat sehingga kita dapat melihat bahwa implementasi kebijakan perubahan status kelembagaan rumah sakit belum mampu meningkatkan kualitas pelayanan yang memenuhi harapan. Penelitian ini bertujuan untuk menilai pengaruh implementasi kebijakan perubahan status kelembagaan rumah sakit terhadap kualitas pelayanan pasien.

\section{Metode}

Penelitian dengan desain kuantitatif ini menggunakan metode explanatory survey dan analisis regresi linier multipel yang menggunakan uji validitas product moment pearson dan uji reliabilitas teknik alpha cronbach serta uji hipotesis path analysis dan uji statistik ( $\mathrm{t}$ ), transformasi data skala likert dengan alat ukur method of successive interval. Populasi mencakup 1.072 pegawai dengan teknik pengambilan sampel stratified random sampling sehingga diperoleh 99 orang dengan instrumen penelitian kuesioner dan wawancara 962 pasien sebagai counter informan.

Penelitian ini menggunakan metode analisis regresi linier multipel yang dilanjutkan dengan path analysis dengan terlebih dahulu melakukan uji validitas dan reliabilitas. Tahapan pendekatan korelasi product moment pearson meliputi penentuan nilai korelasi (r), penentuan nilai $t$ sama dengan hitung, penarikan kaidah keputusan, dan kriteria penafsiran. ${ }^{8}$ Selanjutnya, dilakukan pendekatan alpha cronbach untuk menguji tingkat reliabilitas. Indeks menunjukkan kesamaan gejala yang diukur dan konsistensi instrumen yang digunakan. Data ordinal berupa jawaban tertutup dengan 5 kategori, yaitu sangat setuju (SS), setuju (S), kurang setuju (KS), tidak setuju (TS), dan sangat tidak setuju (STS) yang kemudian ditransformasikan menjadi skala interval dengan skala likert. Jawaban tersebut disesuaikan dengan berbagai pertanyaan tertutup kepada responden yang sesuai dengan situasi dan kondisi faktual.

Setiap jawaban responden diberi skor yang digunakan untuk tingkat pengukuran ordinal. Skor digunakan un- tuk keperluan analisis ke tingkat interval melalui method of successive intervals (MSI) agar secara kuantitatif dapat diolah kemudian data ordinal ditransfer menjadi data interval dalam path analysis. ${ }^{8}$ Penarikan sampel dilakukan dengan teknik stratified random sampling dengan populasi sasaran adalah 1.072 pegawai Rumah Sakit Hasan Sadikin Bandung yang berstatus rumah sakit perusahaan jawatan (Perjan) yang akan berubah menjadi rumah sakit pola pengelolaan keuangan badan layanan umum (PPKBLU). Hal tersebut berhubungan dengan pelayanan perawatan pasien yang meliputi pejabat struktural, kepala staf medis fungsional (SMF), pejabat fungsional, serta pasien yang berjumlah 962 yang terdapat di ruangan paviliun, kelas I, kelas II, kelas III, serta ruangan intensif care sebagai counter informan.

\section{Hasil}

Implementasi kebijakan perubahan status kelembagaan rumah sakit dengan simbol $(\mathrm{X})$ meliputi berbagai faktor, yaitu komunikasi $\left(\mathrm{X}_{1}\right)$, sumber daya $\left(\mathrm{X}_{2}\right)$, sikap pelaksana $\left(\mathrm{X}_{3}\right)$, dan struktur birokrasi $\left(\mathrm{X}_{4}\right)$. Faktor-faktor tersebut berpengaruh secara signifkan terhadap peningkatan kualitas pelayanan pasien (Y) dengan dimensidimensi (reliability, responsiveness, assurance, empathy, and tangibles) (Tabel 1, Tabel 2, dan Tabel 3).

Komunikasi $\left(\mathrm{X}_{1}\right)$ dengan indikator kejelasan, transmisi, dan konsistensi berhubungan erat secara signifikan dengan proses implementasi kebijakan perubahan status kelembagaan rumah sakit. Berdasarkan hasil uji statistik didapatkan koefisien jalur $=0,4980$ dengan pengaruh total secara langsung faktor komunikasi $\left(\mathrm{X}_{1}\right)$ kepada kualitas pelayanan pasien $(\mathrm{Y})=24,80 \%$ yang berarti mendapat dukungan positif. Hasil ini mendukung dan relevan dengan konsep implementasi kebijakan perubahan status kelembagaan rumah sakit yang menuntut aktivitas ko-

Tabel 1. Rekapitulasi Hasil Uji Reliabilitas

\begin{tabular}{lll}
\hline Variabel & Nilai & Keterangan \\
\hline Implementasi kebijakan & 0,853 & Reliabel \\
Kualitas pelayanan & 0,807 & Reliabel \\
\hline
\end{tabular}

Tabel 2. Matriks Invers Korelasi Implementasi Kebijakan

\begin{tabular}{lcccc}
\hline Faktor & $\mathbf{X}_{\mathbf{1}}$ & \multicolumn{1}{c}{$\mathbf{X}_{\mathbf{2}}$} & \multicolumn{1}{c}{$\mathbf{X}_{\mathbf{3}}$} & $\mathbf{X}_{\mathbf{4}}$ \\
\hline $\mathbf{X}_{\mathbf{1}}$ & 1,488394668 & $-0,28936$ & $-0,13943$ & $-0,174879879$ \\
$\mathbf{X}_{\mathbf{2}}$ & $-0,289359249$ & 1,939761 & $-0,62251$ & $-0,310620715$ \\
$\mathbf{X}_{\mathbf{3}}$ & $-0,139427334$ & $-0,62251$ & 1,33308 & $-0,123707187$ \\
$\mathbf{X}_{\mathbf{4}}$ & $-0,174879879$ & $-0,31062$ & $-0,12371$ & 1,692872369 \\
\hline
\end{tabular}

Tabel 3. Pengaruh Implementasi Kebijakan terhadap Kualitas Pelayanan Pasien

\begin{tabular}{lll}
\hline Variabel & F hitung & F tabel \\
\hline -Implementasi kebijakan & 43.772 & 2,40 \\
\hline
\end{tabular}




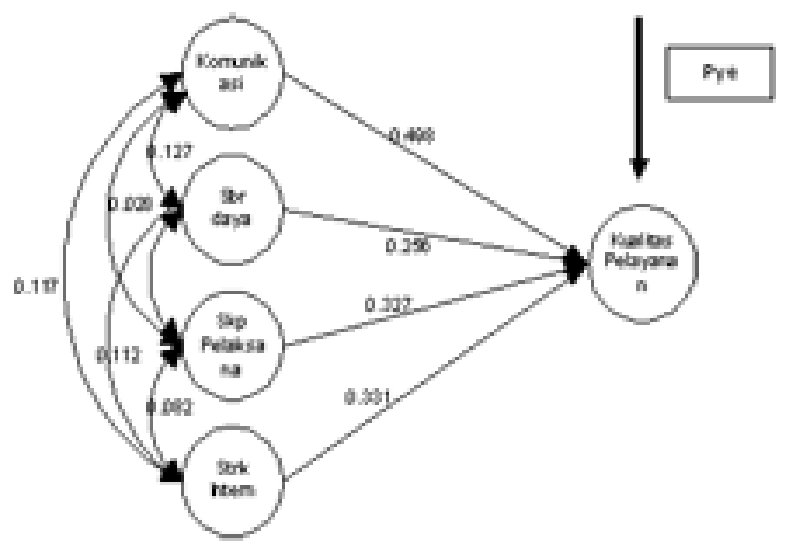

Gambar 1. Path Diagram Variabel Implementasi Kebijakan terhadap Kualitas Pelayanan

munikasi dengan indikator kejelasan skor $872(63,12)$ pada kategori sedang, ketepatan skor $909(65,87)$ pada kategori sedang, dan konsisten skor $303(65,86)$ berada pada kategori sedang.

Hal ini membuktikan bahwa komunikasi antara pengambil kebijakan dan aparatur pelaksana kebijakan belum meningkatkan kualitas pelayanan pasien di rumah sakit sesuai harapan. Berbagai kendala dalam proses implementasi meliputi ketidakjelasan pesan dan salah menafsirkan, ketepatan pesan dan kurang fokus, ketidakkonsistenan pesan yang disampaikan, dan pemahaman pesan yang diterima. Seharusnya, semakin baik komunikasi antara dokter dengan pasien, perawat dengan pasien, pengambil kebijakan dengan aparatur pelaksana, semakin efektif implementasi kebijakan dalam upaya peningkatan kualitas pelayanan pasien di rumah sakit. Faktor sumber daya $\left(\mathrm{X}_{2}\right)$ dengan indikator yang meliputi staf, kemampuan dan keahlian, serta fasilitas menunjukkan keeratan hubungan yang signifikan dalam proses implementasi kebijakan perubahan. Koefisien jalur 0,2563 dengan pengaruh total terhadap kualitas pelayanan pasien $(\mathrm{Y})=6,6 \%$ menunjukkan adanya dukungan positif.

Hasil ini mendukung dan relevan dengan konsep implementasi kebijakan yang menuntut sumber daya dengan indokator yang meliputi staf dengan skor 292 $(66,84)$ pada kategori sedang, dan kemampuan dengan skor $615(66,84)$ pada kategori sedang, fasilitas dengan skor $969(70,1)$ pada kategori baik. Hal tersebut membuktikan bahwa sumber daya yang diolah merupakan penentu kebijakan dan aparatur pelaksana tidak memenuhi upaya konkret meningkatkan kualitas pelayanan pasien di rumah sakit. Berdasarkan Counter information, ditemukan berbagai kendala yang meliputi staf kurang mendukung karena belum memahami maksud dan tujuan, kemampuan sumber daya manusia ku- rang sesuai dengan prosedur dan sistem, penyelesaian kegiatan pelayanan belum sesuai standar, dan fasilitasfasilitas tidak terpenuhi. Semakin baik sumber daya dalam pengambilan kebijakan dan pelaksanaannya, seharusnya semakin efektif implementasi kebijakan (Gambar 1).

Faktor sikap pelaksana $\left(\mathrm{X}_{3}\right)$ dengan indikator kepatuhan, kepribadian, kesadaran, dan kesediaan menunjukkan hubungan yang signifikan dalam proses implementasi kebijakan. Koefisien jalur 0,3271 dengan pengaruh total terhadap kualitas pelayanan pasien (Y) sebesar 10,69\% menunjukkan adanya dukungan dan relevan positif. Hasil ini mendukung dan relevan dengan konsep implementasi kebijakan perubahan status kelembagaan rumah sakit yang menuntut sikap pelaksana dengan indikator staf dengan skor 347 pada kategori baik, kepribadian dengan skor 726 pada kategori baik, dan kesediaan dengan skor 1.124 pada kategori baik. Hal ini membuktikan bahwa sikap pelaksana dalam implementasi kebijakan untuk mendukung penentu kebijakan dan aparatur pelaksana tidak terpenuhi sesuai harapan. Berbagai kendala yang terjadi dalam proses implementasi meliputi tingkat kepatuhan, ketidakyakinan dan ketidakpercayaan, ketiadaan pengakuan, penghargaan dan dukungan, bekerja tanpa motivasi, kecenderungan sebagai penguasa, dan kurangnya perhatian terhadap kepentingan pasien. Semakin baik sikap pelaksana dalam pengambilan kebijakan dengan aparatur pelaksana, semakin efektif implementasi kebijakan.

Faktor struktur birokrasi $\left(\mathrm{X}_{4}\right)$ dengan indikator pembagian tugas yang jelas, kerja sama, pengawasan, dan prosedur menunjukkan hubungan yang signifikan dalam proses implementasi kebijakan. Berdasarkan hasil uji statistik diperoleh koefisien jalur 0,3316 dengan pengaruh total struktur birokrasi terhadap kualitas pelayanan pasien (Y) sebesar 10,9\% yang berarti mendapat dukungan positif dan relevan untuk memperlancar pelaksanaan kegiatan pelayanan. Hasil ini mendukung dan relevan dengan konsep implementasi kebijakan yang menuntut struktur birokrasi dengan indikator pembagian tugas yang jelas dengan skor $1023(74,1 \%)$ pada kategori baik, kerja sama dengan skor $699(75,9 \%)$ pada kategori baik, pengawasan dengan skor $632(68,7 \%)$ pada kategori baik, dan prosedur dengan skor $731(79,5 \%)$ pada kategori baik.

Hal tersebut membuktikan bahwa struktur birokrasi mendukung proses pengambilan kebijakan dan aparatur pelaksana kebijakan. Sebagai dampak upaya konkret yang tidak sesuai harapan, timbul berbagai kendala dalam proses implementasi yang meliputi struktur birokrasi melekat pada jabatan dan tidak fleksibel dalam menjalankan aktivitas pelayanan, ketidakjelasan struktur sampai tingkat pelaksana, masih kental dengan gaya birokrat formal, kurang dukungan dan sinergitas dalam 


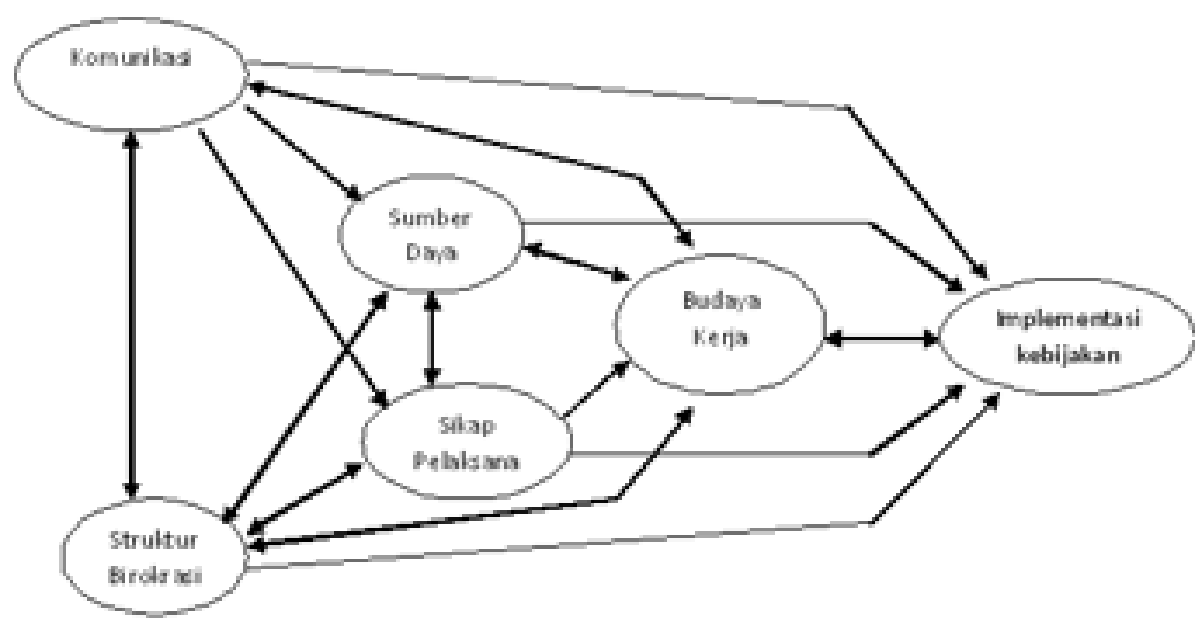

Gambar 2. Model Pengembangan Teori Implementasi Kebijakan Publik

Tabel 4. Hasil Pengujian Variabel Implementasi Kebijakan terhadap Kualitas Pelayanan

\begin{tabular}{llll}
\hline \multicolumn{1}{c}{ Dimensi } & Uji t hitung & $\mathbf{t}_{\text {tabel }} \mathbf{( 5 \% )}$ & Keterangan \\
\hline Komunikasi & 6.60851 & 1,99 & Signifikan \\
Sumber daya & 2.97903 & & Signifikan \\
Sikap pelaksana & 4.58581 & & Signifikan \\
Struktur birokrasi & 4.12625 & & Signifikan \\
\hline
\end{tabular}

bekerja, serta kecenderungan struktur birokrasi yang kurang memerhatikan kepentingan pasien. Semakin baik struktur birokrasi sebagai instrumen dalam pengambilan kebijakan dengan aparatur pelaksana, semakin efektif pula implementasi kebijakan (Tabel 4).

\section{Pembahasan}

Penelitian ini berorientasi pada teori implementasi kebijakan publik sebagai konsekuensi logis. Pertama, teori Edwards dengan 4 faktor implementasi yang meliputi komunikasi, sumber daya, sikap pelaksana, dan struktur birokrasi yang merupakan suatu penegasan dengan menonjolkan eksistensi aparatur birokrasi pemerintahan sebagai aktor dan pelaksana kebijakan.2,9,10 Kedua, teori tersebut belum mempertimbangkan kondisi riil empirikal masyarakat sebagai basis implementasi kebijakan, khususnya dalam memperhatikan pengembangan faktor lain yang meliputi budaya kerja. ${ }^{11,12}$ Setiap produk kebijakan yang akan diimplementasikan dipastikan bermuara langsung dengan masyarakat sebagai basis pelaksanaan tahapan kebijakan publik. Oleh sebab itu, dapat ditegaskan bahwa proses implementasi kebijakan, selain memerhatikan dan menerapkan keempat faktor implementasi kebijakan menurut Edwards tersebut, perlu memperhatikan faktor budaya kerja pegawai tempat produk kebijakan tersebut diimplementasikan.

Untuk itu, diperlukan faktor budaya kerja yang di- kontruksikan sebagai model pengembangan dalam teori implementasi kebijakan. Hal tersebut merupakan norma yang dianut sebagai prinsip dasar yang mengikat kekerabatan perorangan untuk berperilaku dalam pelayanan pasien di rumah sakit. ${ }^{11}$ Berdasarkan pengembangan teori implementasi kebijakan Edwards tersebut, dapat dikonstruksikan model pengembangan (Gambar 2).

Faktor kelima model pengembangan teori implementasi kebijakan adalah budaya kerja yang merupakan standar berperilaku sebagai prinsip dasar yang mengikat kekerabatan individu untuk berperilaku dalam pelayanan kesehatan. ${ }^{11}$ Dimensi kelembagaan rumah sakit zaman dulu masih bersifat misionaris berbau bahasa asing dan struktur organisasi kelembagaan masih berupa line and staff. Sejak zaman penjajahan Belanda hingga kini, rumah sakit yang merupakan warisan zaman penjajahan, masih dikenal nama-nama yang mempertahankan peperangan. Kelembagaan berada di bawah kepemimpinan seorang direktur dengan jabatan rangkap untuk memberikan pelayanan. Rumah sakit milik pemerintah Belanda secara bertahap diserahkan. Kepada budaya kerja mengelola lembaga rumah sakit yang mengenal kepemimpinan yang sangat disiplin dan profesional hanya untuk kepentingan pelayanan masyarakat kurang mampu. Budaya kerja pegawai dengan sikap dan perilaku yang tidak mengharapkan perubahan secara turun-temurun mempunyai kebiasaan dan membudaya dalam suatu kelompok. 12

Konsep budaya kerja adalah suatu falsafah yang disadari oleh pandangan hidup sebagai nilai-nilai yang menjadi sifat, kebiasaan, dan kekuatan pendorong serta membudaya dalam kehidupan suatu kelompok masyarakat atau organisasi. ${ }^{13}$ Dengan kata lain, budaya kerja merupakan salah satu komponen kualitas manusia yang sangat melekat dengan identitas bangsa dan menjadi to- 
lok ukur dasar pembangunan. ${ }^{14,15}$ Budaya sudah dikenal manusia sejak lama, tetapi belum disadari bahwa keberhasilan kerja itu berakar pada nilai, perilaku, dan sikap yang menjadi kebiasaan. Nilai-nilai tersebut bermula dari kebiasaan, agama, norma, dan kaidah yang menjadi keyakinan dalam sikap dan perilaku kerja suatu organisasi. ${ }^{16,17}$

Dimensi motivasi penyedia pelayanan di rumah sakit mengikuti perubahan dan perkembangan serta tantangan sebagai industri jasa pelayanan. ${ }^{18,19}$ Hal ini tampak pada eksistensi motivasi pelayanan pasien yang dilayani dengan tanggap secara cepat dan tepat, tidak mengenal perbedaan pangkat, golongan, suku, status, ekonomi, agama, serta menjunjung tinggi semangat toleransi pelayanan pasien dalam bingkai nasionalisme. Mentalitas dan moralitas aparatur pelaksana kebijakan merupakan dimensi penting yang menentukan keberhasilan setiap produk kebijakan yang diimplementasikan. Kemampuan petugas sudah sesuai dengan tugas, peran, dan fungsi organisasi rumah sakit. Secara operasional, budaya kerja adalah sekelompok pikiran dasar atau program mental yang dapat dimanfaatkan untuk meningkatkan efisiensi kerja dan kerja sama manusia yang dimiliki oleh suatu golongan masyarakat. ${ }^{20}$

Peningkatan kemampuan dan keahlian aparatur pelaksana melalui pelatihan dan keterampilan untuk meningkatkan kualitas pelayanan telah sesuai dengan perkembangan dan perubahan kemajuan teknologi canggih kedokteran dan kebutuhan organisasi. Melaksanakan budaya kerja mempunyai arti yang sangat dalam karena akan mengubah sikap dan perilaku sumber daya manusia sesuai dengan nilai dan norma yang ada di lingkungannya. Ada korelasi positif dan signifikan antara budaya organisasi dengan prestasi karyawan. Oleh karena itu, budaya kerja menjadi salah satu hal yang perlu diperhatikan dalam meningkatkan kualitas pelayanan. 21,22

Faktor budaya kerja perlu diperhatikan dalam tatanan implementasi kebijakan publik. 11,23 Selain itu, budaya kerja harus didukung komitmen kepemimpinan dan karyawan karena pengembangan budaya kerja membutuhkan etika kerja sama yang akan mengefektifkan sistem kerja dengan pihak lain. ${ }^{24}$ Oleh karena itu, tidak sedikit produk kebijakan pemerintah mengalami tantangan ketika akan diimplementasikan dalam proses pembuatan kebijakan atas interaksi keterlibatan kekuasaan. ${ }^{25}$

\section{Kesimpulan}

Implementasi kebijakan perubahan status kelembagaan rumah sakit berpengaruh terhadap kualitas pelayanan secara signifikan. Faktor-faktor implementasi kebijakan yang meliputi komunikasi, sumber daya, sikap pelaksana, dan struktur birokrasi memiliki pengaruh yang cukup besar terhadap kualitas pelayanan. Dari keempat faktor tersebut, faktor komunikasi berpengaruh paling besar, sementara sumber daya berpengaruh paling kecil. Hal ini membuktikan bahwa eksistensi sumber daya belum menjadi perhatian serius dari rumah sakit. Faktor lain yang melengkapi konsep implementasi kebijakan adalah faktor budaya kerja sebagai basis implementasi kebijakan publik dalam kelembagaan rumah sakit.

\section{Saran}

Perlu dilakukan penelitian kualitatif untuk menganalisis faktor-faktor implementasi kebijakan lain secara mendalam. Kualitas pelayanan pasien perlu didukung sumber daya manusia yang mempunyai kemampuan, keahlian, dan keterampilan dari segi pelayanan. Kepedulian pegawai ruangan pelayanan perlu didukung sikap dan perilaku profesional sesuai kebutuhan dan tuntutan pasien. Peningkatan efektivitas komunikasi, sumber daya, sikap pelaksana, dan struktur birokrasi dapat dilakukan dengan memperbanyak jenis media komunikasi dengan memanfaatkan teknologi komputerisasi. Peningkatan sumber daya dilakukan dengan meningkatkan kualitas pelaksana kebijakan, dukungan dana dan informasi, serta fasilitas pendukung. Peningkatan kualitas implementor dilakukan dengan meningkatkan kemampuan dan profesionalisme aparatur melalui pendidikan dan pelatihan. Sikap pelaksana ditingkatkan dengan pemantapan pemahaman tentang pentingnya kebijakan perubahan status kelembagaan rumah sakit. Penghargaan perlu diberikan kepada aparatur yang benar-benar melaksanakan tugas dan sanksi diberikan kepada aparatur yang tidak mendukung.

\section{Daftar Pustaka}

1. Trisnantoro L. Aspek strategis manajemen rumah sakit. Yogyakarta: Penerbit Andi; 2005.

2. Agustino. Politik dan kebijakan publik. Lembaga Penelitian Universitas Padjadjaran, Asosiasi Ilmu Politik Indonesia, Pusat Penelitian Kebijakan Publik dan Pengembangan Wilayah. Bandung: Universitas Padjadjaran; 2006.

3. Aditama YT. Manajemen administrasi rumah sakit. Edisi kedua. Jakarta: UI Press; 2004.

4. Trisnantoro L. Memahami penggunaan ilmu ekonomi dalam manajemen rumah sakit. Yogyakarta: Gajah Mada University Press; 2006.

5. Riyadi. Pola transformasi rumah sakit umum daerah: perubahan bentuk kelembagaan atau pengelolaan keuangan. Jurnal MARSI. 2005; 5 (4).

6. Thabrany H. Rumah sakit BUMD harus merubah bentuk. Jurnal MARSI. 2003; IV.

7. Ayuningtyas D. Analisis politik dan kebijakan pembiayaan rumah sakit pemerintah DKI Jakarta. Kesmas Jurnal Kesehatan Masyarakat Nasional. 2010; 5 (3): 116-24.

8. Tobing HL. Analisa data untuk penelitian survey dengan LISREL. Fakultas Matematika dan Ilmu Pengetahuan AlamUniversitas Padjadjaran. Bandung: Universitas Padjadjaran; 2004.

9. Nugroho R. Kebijakan publik formulasi implementasi dan evaluasi. Jakarta: Gramedia; 2004. 